\title{
Impact d'un traitement antioxydant sur le transfert de gène par un vecteur $A A V r$ dans un modèle murin de la dystrophie musculaire de Duchenne
}

\author{
Jean-Baptiste Dupont, Benoît Tournaire, Romain Durand, Béatrice Marolleau, Émilie Bertil, \\ Christophe Georger, Émilie Lecomte, Benjamin Cogné, Bernard Gjata, \\ Laetitia Van Wittenberghe, Alban Vignaud Richard, O. Snyder, Philippe Moullier, Adrien Léger
}

Jean-Baptiste Dupont Benoît Tournaire Romain Durand Emilie Lecomte Benjamin Cogné Adrien Léger UMR Inserm 1089, Atlantic Gene Therapies, Nantes, France jeanbaptiste.dupont@ univ-nantes.fr Béatrice Marolleau Emilie Bertil

Christophe Georger

Bernard Gjata

Laetitia van

Wittenberghe

Alban Vignaud

Généthon, Evry, France

Richard $\mathbf{0}$. Snyder

UMR Inserm 1089 ,

Atlantic Gene Therapies,

Nantes, France

Department of Molecular

Genetics

and Microbiology,

University of Florida

College of Medicine,

Gainesville, Florida,

États-Unis

Center of Excellence

for Regenerative Health

Biotechnology, University

of Florida College

of Medicine, Gainesville,

Florida, États-Unis

Philippe Moullier

UMR Inserm 1089

Atlantic Gene Therapies,

Nantes, France

Center of Excellence

for Regenerative Health

Biotechnology, University

of Florida College

of Medicine, Gainesville,

Florida, États-Unis
Les vecteurs recombinants dérivés du virus adénoassocié (AAVr) sont des outils prometteurs pour la thérapie génique de la dystrophie musculaire de Duchenne (DMD). Plusieurs études menées chez des modèles murins ou canins de la DMD ont en effet décrit des améliorations phénotypiques significatives sans effet toxique notable suite à l'injection d'importantes quantités de vecteur [1, 2]. Même si ces études sont prometteuses, le maintien à long terme de l'expression du transgène demeure peu ou pas documenté. Dans plusieurs modèles de souris DMD, notre équipe et d'autres laboratoires avons ainsi démontré que cette expression diminuait progressivement, même après injection de doses de vecteurs AAVr cliniquement pertinentes [3, 4]. En corrélation, nous avons observé une perte des génomes de vecteurs résultant de la nécrose des cellules musculaires DMD, ainsi que des dommages oxydatifs affectant les molécules d'ARNm du transgène. Ces observations soulignent l'importance du contexte tissulaire dans lequel sont injectés les vecteurs $\mathrm{AAVr}$, et l'impact majeur qu'il peut avoir sur leur efficacité. Mais elles permettent également de dégager des perspectives d'amélioration: en neutralisant ces "facteurs de restriction " préalablement à l'injection d'AAVr, la persistance et l'efficacité de ces vecteurs pourraient se trouver renforcées. Dans le cas de la $\mathrm{DMD}$, le stress oxydatif semble occuper une position centrale à la fois dans la physiopathologie cellulaire, et dans la dégradation de l'ARNm du transgène $[4,5]$. Par conséquent, nous avons développé une stratégie innovante utilisant un composé antioxydant fréquemment employé en médecine humaine. Des souris DMD, prétraitées ou non par cette molécule, ont reçu dans un deuxième temps un vecteur $\mathrm{AAVr}$ portant un transgène rapporteur. L'efficacité de transduction, l'expression et l'activité du transgène ont ensuite été mesurées deux mois après injection. Le résultat de cette approche innovante sera certainement précurseur pour de futurs protocoles de traitement combinatoires pour la DMD, alliant l'efficacité de molécules pharmacologiques à celle des vecteurs $\mathrm{AAVr}$ de thérapie génique.

\section{Impact of an antioxidant treatment on rAAV-mediated gene transfer in a mouse model of Duchenne muscular dystrophy}

Recombinant adeno-associated virus (rAAV)-based vectors are promising tools for the gene therapy of Duchenne muscular dystrophy (DMD) (Figure 1). Several studies in murine and canine models of DMD reported significant phenotype improvements without any notable toxicity following the injection of substantial amounts of vector $[1,2]$. While this has raised hope for future translations in DMD patients, long term maintenance of the therapeutic benefits is an important, and yet unresolved issue. In previous studies conducted in DMD mice, we and others have demonstrated that $\mathrm{rAAV}$-mediated transgene expression is progressively reduced, even after injection of clinically relevant vector doses [3, 4]. This could be explained, at least in part, by the loss of vector genomes resulting from muscle cell necrosis but also by the oxidative damage affecting transgene mRNA molecules. These elements support the fact that the tissue context in which rAAV vectors are delivered is of critical importance and can significantly affect their efficiency. But they also open new avenues for improvement, since we can now consider counteracting these "restriction" phenotypes prior to rAAV injection. In the case of DMD, oxidative stress seems to occupy a central position in both muscle cell pathophysiology and rAAV transgene mRNA degradation $[4,5]$. Therefore, we designed an innovative strategy using a relevant antioxidant agent routinely used in human 


\section{Impact of an antioxidant treatment on recombinant adeno- associated virus (rAAV) vector-mediated gene transfer in a mouse model of Duchenne muscular dystrophy}

Jean-Baptiste Dupont ${ }^{1}$, Benoît Tournaire ${ }^{1}$, Romain Durand ${ }^{1}$, Béatrice Marolleau' ${ }^{2}$, Emilie Bertil ${ }^{2}$, Christophe Georger ${ }^{2}$, Emilie Lecomte ${ }^{1}$, Benjamin Cogné ${ }^{1}$ Bernard Gjata ${ }^{2}$, Laetitia van Wittenberghe ${ }^{2}$, Alban Vignaud ${ }^{2}$, Richard O. Snyder ${ }^{1,3,4}$, Philippe Moullier $^{1,4}$ and Adrien Léger

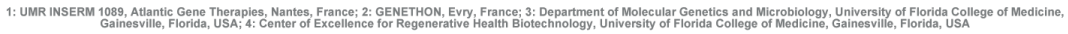

Contact: jeanbaptiste.dupont@univ-nantes.fr

(d) Recombinant adeno-associated virus (rAAV)

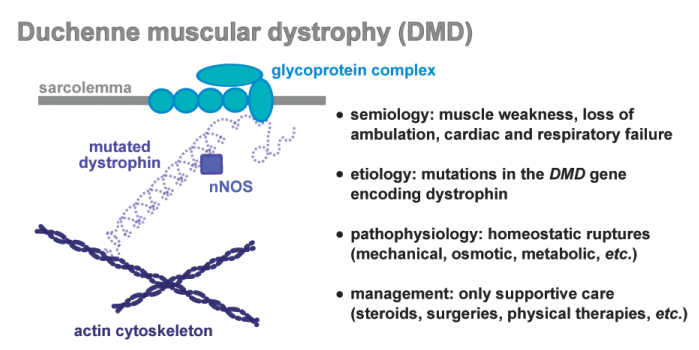

Duchenne muscular dystrophy (DMD)

Hypothesis: Specific DMD phenotypes impair one or several step(s) of the rAAV transduction process What are these "restriction factors" and can they be counteracted?

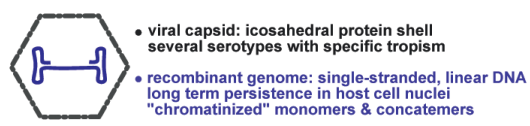

IAAV vectors in DMD animal models

- more than 30 studies with different transgenes (U7, $\mu$ Dys, Fst, nNOS, etc.) - average injected dose: around $1.0 \mathrm{E}+14$ vector genomes $(\mathrm{vg}) / \mathrm{kg}$ - studies rarely continued over 6 months

- loss of transgene expression and vector genomes over tim

Study plan in 3 successive steps:

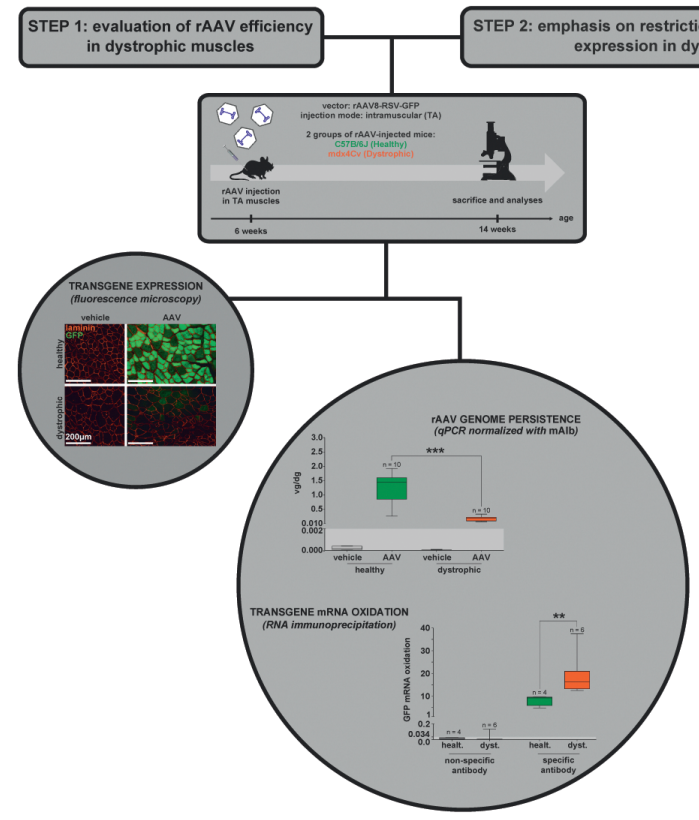

Conclusion \& future directions

- sharp reduction of rAAV efficiency in $\mathrm{mdx} \times \mathbf{C} v$ muscles

- vector genome persistence and transgene mRNA metabolism

(oxidative status) are affected

improvement with pharmacology? Many parameters to consider...

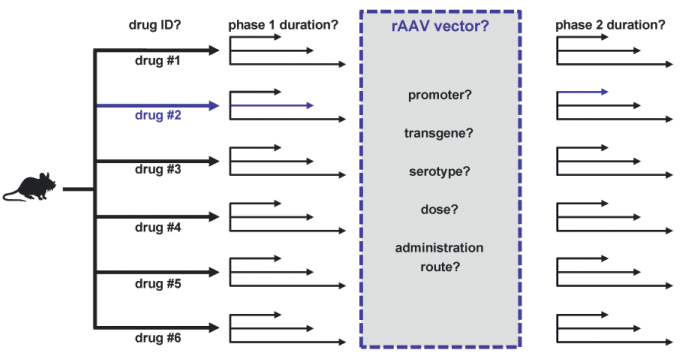

factors inhibiting transgene
ophic muscles

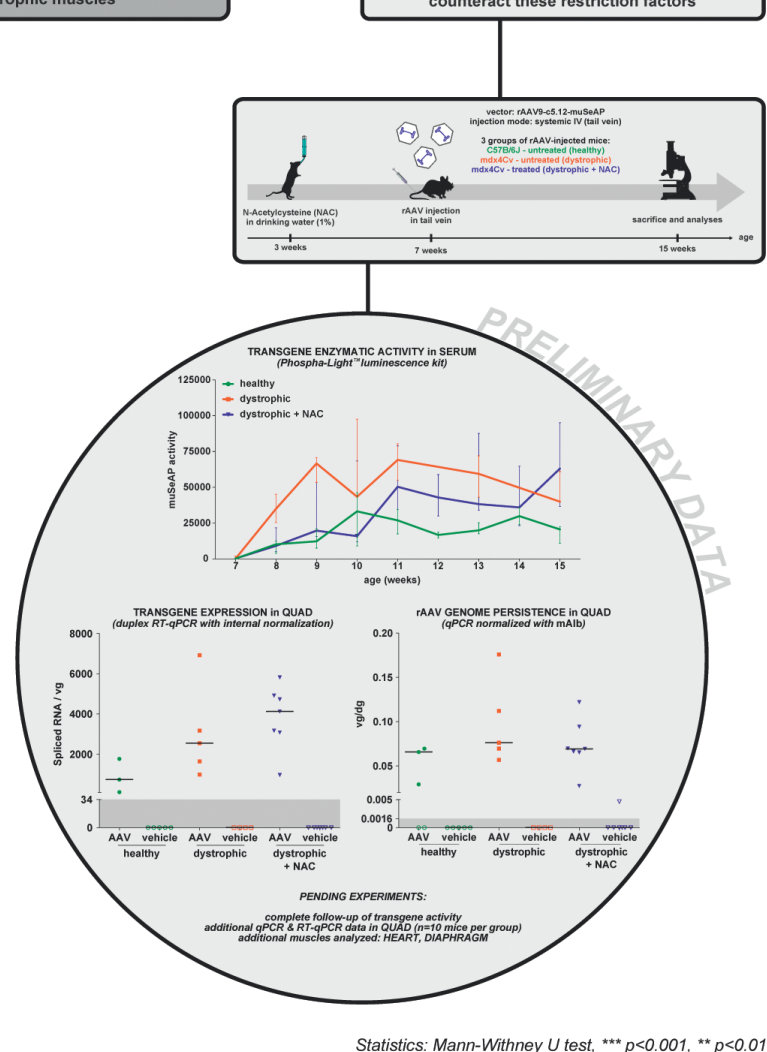

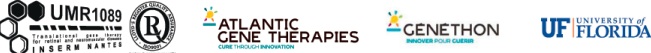

)) PARY DE LA LORE AFMTELETHON\%

州! Inserm 背a言 
medicine. DMD mice, pre-treated or not with this compound, were subsequently injected with a rAAV vector carrying a reporter transgene. The transduction efficiency, together with the expression and activity of the transgene, were monitored and compared two months later. The outcome of this innovative approach will certainly pave the way for future combinatorial protocols using pharmacological agents and rAAV vectors in DMD muscles.

Impact of an antioxidant treatment on recombinant adeno-associated virus (rAAV) vectormediated gene transfer in a mouse model of Duchenne muscular dystrophy

\section{LIENS D'INTÉRÊT}

Les auteurs déclarent n'avoir aucun lien d'intérêt concernant les données publiées dans cet article.

\section{RÉFÉRENCES}

1. Le Guiner C, Montus M, Servais L, et al. Forelimb treatment in a large cohort of dystrophic dogs supports delivery of a recombinant AAV for exon skipping in Duchenne patients. Mol Ther $J$ Am Soc Gene Ther 2014 ; 22 : 1923-35.

2. Kawecka K, Theodoulides M, Hasoglu Y, et al. Adeno-associated virus (AAV) mediated dystrophin gene transfer studies and exon skipping strategies for Duchenne muscular dystrophy (DMD). Curr Gene Ther 2015 ; 15 : 395-415.

3. Le Hir M, Goyenvalle A, Peccate C, et al. AAV genome loss from dystrophic mouse muscles during AAV-U7 snRNA-mediated exon-skipping therapy. Mol Ther J Am Soc Gene Ther 2013; 21 : 1551-8.

4. Dupont JB, Tournaire B, Georger C, et al. Short-lived recombinant adeno-associated virus transgene expression in dystrophic muscle is associated with oxidative damage to transgene mRNA. Mol Ther Methods Clin Dev 2015 ; 2 : 15010.

5. Tidball JG, Wehling-Henricks $M$. The role of free radicals in the pathophysiology of muscular dystrophy. J Appl Physiol 2007 ; $102: 1677-86$ 